\section{КОМЕДИЈА КАО ЕСТЕТСКИ \\ ОДГОВОР НА ДРУШТВЕНЕ ИЗАЗОВЕ}

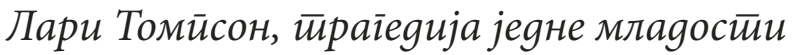 \\ Душана Ковачевића - пример српске \\ постмодерне црне комедије
}

Академија уметности

Универзитета у Новом Саду

Апстракт: У раду се анализира комедиографски приступ Душана

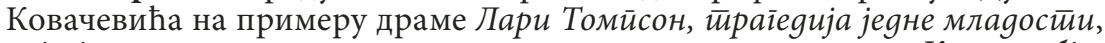
која је настала на средини стваралачког пута овог писца. Комад обједињује особености претходног периода, у коме су настајале комедије

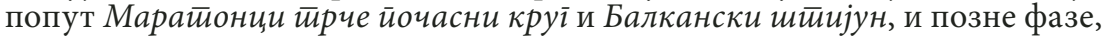
у којој су драме попут Генералне ӣробе самоубисиива. Дело Душана Ковачевића се разматра из историјског контекста политичких дешавања деведесетих година у Србији, позоришног и уметничког контекста у коме настаје дело и изводи као позоришна представа, као и контекста српског комедиографског писања од Стерије до Ковачевића. Комад се у методолошком смислу ситуира и у истраживања дела Душана Ковачевића из перспективе теоријских промишљања у духу постмодерне, која су била актуелна у време настанка комада, и поставља пред теоријску призму најпознатијих истраживања комедије, смеха и комике.

Кључне речи: комедија, црни хумор, Душан Ковачевић, апсурд, позориште, постмодерна

Хумор има своје местио у свим уметиностиима, али комична gрама је юеїов gом. (Лангер 1981: 391)

\title{
Увод
}

Увидом у Годишғаке йозоришӣа Србије 2015/16 долазимо до сазнања да су од укупне српске драмске баштине на сцени стално актуелне комедије Јована Стерије Поповића, Бранислава Нушића, Александра Поповића и Душана Ковачевића. Уз ове комаде, од новијих дела потврђене вредности како у позоришту тако и у савременој театрологији извођене су још и три драме Љубомира Симовића (Хасанаіиница, Чуgо у Шаріану и Пуйујуће йозоришиее Шойаловић), од којих макар она најизвођенија, Чуgo у Шаріану, има у себи елементе комедије. Комедија је наш најживљи (боље речено једини у позоришту увек живи) драмски жанр. Од Стерије, преко Трифковића, Нушића, Александра Поповића, до Душана Ковачевића може се повући фина, златна нит континуитета српске комедије од средине 19. до почетка 21. века. Душан Ковачевић представља последњу „карику“ у том низу. 
Успон Душана Ковачевића као комедиографа поклапа се са временом великих друштвених промена - крај Титове ере и успон и пад политике коју је репрезентовао Слободан Милошевић. Дела комедиографа (узмимо за пример Стерију и његово виђење револуције из 1848. године у комедији Роgољуйци или Нушићевих комедија насталих у турбулентним првим деценијама 20. века у Србији, СХС и Краљевини Југославији) јесу снажна уметничка сведочанства о изазовима епохе у којој су настајала. Тако и Ковачевићеве комедије можемо посматрати као сведочанства о променама у српском друштву на крају 20. века и комедији као естетском одговору на друштвене изазове. У анализи ћемо се бавити комедијама Душана Ковачевића

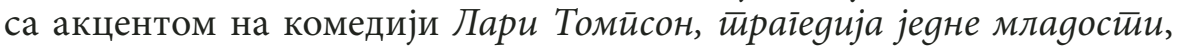
драми која у себи обједињује Ковачевићеве комедиографске приступе из седамдесетих и осамдесетих година са онима које ће примењивати од краја деведесетих до данас. У овом раду покушаћемо да кроз

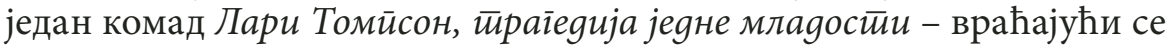
уназад до Марайонаца и идући унапред до Докйора Шустиера, Генералне йробе самоубисиива и Хийнозе јеgне тубави - покажемо да се бројни мотиви и комедиографски „алати“ из претходних комада сажимају у овом комаду. Проучаваћемо које квалитете и особености поседују комедије Душана Ковачевића и како се стапају у Ларију Томйсону. Користићемо теоријску апаратуру која се бави комедијом од Аристотела до данас, као и текстовима аутора и ауторки који су се посебно бавили комедијама Душана Ковачевића. Анализираћемо драме из овог периода зато што је то најплоднији период стварања овог писца и време његове потпуне друштвене потврде као једног од водећих драмских писаца овог доба. Душан Ковачевић у овом периоду уводи нов приступ комичном. Уз апсурд и црну комедију, која је била особеност његових раних комада, у комадима зрелог периода приметно је појачано саосећање према ликовима. По овој особини, приступ комичном Душана Ковачевића постаје близак Пиранделовом појму хуморизма. Пирандело комично одређује као запажање противног, а хуморизам се заснива на осећању противног које у себи садржи почетак саосећања са оним коме се смејемо (Пирандело 1963: 972). У историји филозофије и теорији књижевности изнет је читав низ различитих теорија о томе чему се смејемо, шта је хумор и каква је њихова веза са комедијом, о чему се детаљно можемо обавестити у Увоgу у йеорије смеха (Перишић 2010). За ово излагање инспиративна је Женетова идеја о томе да нема комичних предмета, има само комичних релација те да је комично:

[...] истовремено једно име (поименичени придев) жанра или стила, као симфонијско, романескно или имйресионисииччко и вредносни суд. Управо у томе је типично естетски предикат. Статус комедије је мало деликатнији, јер комедија се може одредити по објективним цртама [...] 
које одређују жанровски статус независно од сваког заиста комичног ефекта. (Женет 2002: 155)

На комично и хумор у комедијама Душана Ковачевића могу се применити следеће речи Сузан Лангер: „У комедији постоје сви ступњеви хумора, од брзог и духовитог одговора [...] до бесмислице [...]. Хумор има своје место у свим уметностима, али комична драма је његов дом“ (Лангер 1981: 391). Код Лангерове се јавља идеја, коју заступа и Женет, да комедија мора имати срећан крај. На њу се надовезује запажање да комедија слави жељу за животом, о чему, поред Лангерове, пише и Фрај у есеју „Мит пролећа: Комедија“ (Frye 1979). Душан Ковачевић у својим делима доводи у питање ове идеје о комедији јер поставља питање шта је то, заправо, срећан крај. Да ли се срећним крајем може сматрати „привремено оживљавање“ као у Ларију Томйсону, или враћање побуњеног сина у окриље породице као у Марайонцима? Комедију бројни проучаваоци, међу којима и наведени Женет и Лангерова, сматрају жанром који слави живот. Но, предмет Ковачевићевог интересовања у комедијама је смрт и то од Марайонациа, па све до Ларија Томйсона, Докииора Шусиеера и Генералне йробе самоубистива. На његове комедије пре би се могла применити опаска Ерика Бентлија „да жеља за животом није пука љубав за животом. То је такође и похлепа“. (Bentley 1965: 304) У овој тачки, комедија Душана Ковачевића приближава се театру апсурда. Апсурд је иманентан у комичном. То је приметио још Кант: „У свему што треба да изазове неки жив, грохотан смех мора да се налази нека бесмислица [...]. Смех представља један афекат који пониче из изненадног преображаја напрегнутог очекивања у ништа“ (Кант 1991: 220-221). Међутим, театар апсурда је већу пажњу у теорији позоришта добио тек у 20. веку и то прво као негирање театра - антитеатар, којим се потврђује театар. Ово је приметио и Бодријар у свом делу Симулакруми и симулащија (Бодријар 1991). Испитивање односа реалности, симулације и симулакрума јесте питање естетике постмодерне и чини се да је на први поглед у слабој вези са комедијом. Но, управо зато што се бави питањима шта је живот, а шта смрт и да ли живот може бити симулација смрти, или је смрт симулација живота, ова размишљања из домена постмодерне филозофије треба укључити у истраживање о Ковачевићевом делу.

Свако истраживање драмског у смислу европске традиције нужно полази од Аристотела. Старогрчки филозоф каже да је комедија: „подражавање нижег карактера, али не у пуном обиму онога што је рђаво, него онога што је ружно, а смешно је само део тога. Jер, смешно је нека грешка и ругоба која не доноси бол и није погубна“ (Аристотел 1988: 52). Но, када је Душан Ковачевић у питању то никако није случај. Напротив! Он се у својим комедијама управо бави великим, слободно се може рећи катастрофалним, по живот и суштину живота и људског друштва фаталним манама. То је одлика 


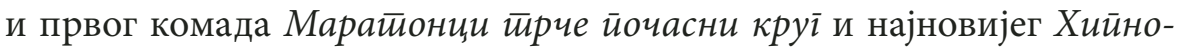
за јеgне љубави. Његов хумор је хумор са погледом на смрт - „да умреш од смеха“, што би рекао Женет у истоименом есеју (Женет 2002). Његови ликови су стога много ближи жаријевским фигурама, ситуацијама из драме апсурда, као и црној комедији, него класичној комедији. Увођење апсурда отвара читаво једно ново поље размишљања о комедији. Да ли је комедија са примесом апсурда у ствари црна комедија, како је разуме Стајан, или трагикомедија, како је разуме Карл Гутке? Или су црна комедија и трагикомедија у ствари исти жанр са два различита имена? Пишући о црној комедији и трагикомедији, Стајан и Гутке се позивају на драмска дела истих аутора - Шекспира, Ибзена, Јонеска и Бекета. С аспекта теорије, обојица истичу значај Пиранделовог есеја о хуморизму. Наведени драмски писци теже да у својим делима споје амбивалентна осећања управо онако како их савремени човек склон комплексном па и противуречном сагледавању живота и сопствене личности доживљава. Комично у савременој драматургији потцртава трагичан патос јунака, чинећи га ближим замршеним осећањима савременог човека (Styan 1962: 250). Гутке се по питању „савремености“ не слаже сасвим са Стајаном, већ сматра да:

Ниједан књижевни жанр [...] у својој суштини није исход формалних особености и стилских карактеристика или тематике која се обрађује, већ произлази из специфичне перцепције, специфичног сагледавања тематике, живота, човека и света. Стога нам сваки књижевни жанр показује специфичне човекове могућности разумевања самог себе. Изучавање књижевних жанрова је, сходно томе, у суштини прилог антропологији: прилог нашем познавању човековог сагледавања себе самог кроз векове. [...] трагикомедија уједињује две крајности за које је човек способан у својој евалуацији самог себе. Човек је једино биће које се смеје и плаче. И смех и плач су реакције на опажање човековог положаја in extremis. (Гутке 2007: 177-178)

Ипак, дискусија око тога да ли су трагикомедија и црна комедија један или два жанра, те да ли изучавање жанрова треба да буде део антрополошких или књижевнотеоријских студија - одвела би нас далеко од наше главне теме. Ова два унеколико слична, али ипак и различита става драгоцена су нам зато што указују да однос према жанру зависи од односа писца према свету. Ковачевић кроз комично говори о трагичности људске егзистенције на Балкану на крају 20. века, о појединцима, њиховим породицама које су (не) намерни (са)учесници у потпуном пропадању. Због тога је важно узети у обзир и контекст његовог стварања и контекст у коме је настало конкретно дело, као и дела српских теоретичара, критичара и театролога који су значајно допринели разумевању и потврђивању дела Душана Ковачевића. 
У том смислу веома је значајан Владимир Стаменковић који је практично први препознао вредност овог писца. Пишући збирно о Ковачевићевим драмама у есеју „Опаска о људској природи“ наслућује да ће Ковачевићеви комади након Свейо̄ Георіија постајати све опорији и окрутнији и да ће у њима долазити до инверзије комичког и драмског (Стаменковић 1987: 290). И заиста, како се ситуација у друштву компликовала тако су комади Душана Ковачевића постајали све мрачнији, замршенији и компликованији. Владимир Стаменковић у овом есеју наводи да је особеност Ковачевићевих комада велики виталитет његових ликова, што јесте особина комедије, али Ковачевићеви ликови имају једну опсесивну и хистеричну ноту, која је у тесној вези за похлепом, али и моментом увида на самом крају комада који јунаке приближава драмским ликовима (драма у ужем смислу). Спој витализма, опсесивности и хистерије доводи до искривљења у коме комедија више није у славу живота већ метафора смрти, односно потпуног пропадања, што је далеко, веома далеко од Аристотелове идеје комедије. То је особеност комедије и у Ларију Томйсону.

Када се Лари Томйсон разматра у контексту рада Душана Ковачевића, видимо да је настао пет година након његове претходне дра-

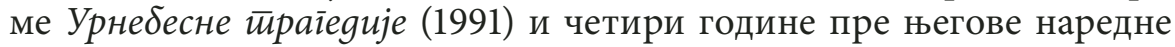
драме Доктиор Шустиер (2000). У то време Душан Ковачевић има две Стеријине награде: Балкански шӣијун (1984), Свейи Георіије убива aжgaxy (1987), и награду Стеријиног позорја за комедију Клаусйрофобична комеgија (1988). У време када је писао Ларија Томйсона, Душан Ковачевић је био професор на Факултету драмских уметности у Београду, на Катедри за драматургију. Недуго након праизведбе овог комада и после признавања победе опозиције на локалним изборима, Душан Ковачевић је постављен за директора Звездара театра. На тој функцији је остао до данас.

\section{Лари Томпсон, трагедија једне младости - увид у несрећу једне земље из угла црне комедије}

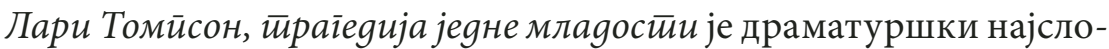
женија драма Душана Ковачевића. Лари Томпсон је измишљени млади јунак измишљене аустралијске „сапунице“ коју гледа породица Нос. Док породица опчињено прати серију, у другој соби истог стана млади глумац Стефан Нос одлучује да више неће да глуми и живи. Његово одустајање од глуме постаје разлог за пиранделовско позориште у позоришту, у коме управница Катарина и глумац Бели импровизују да би у позоришту задржали публику којој ласкају називајући је Величанственом публиком. Величанствену Публику игра права публика пред којом се одиграва ова Ковачевићева драма, док прави глумци играју измишљене глумце који симули- 
рају позориште и измишљену породицу Нос која живи опчињена измишљеном серијом. Неочекиваним заокретима у радњи писац чини да чланови породице прво гину, а затим се сви, осим глумца, буде у новом „привидном животу“, односно симулакруму - да употребимо Бодријаров израз. Глумац једини не оживљава у симулакруму живота, јер је лажни живот своје породице заменио позоришном илузијом. Да ли је позориште симулација живота, или је реалније од стварног живота грађанина који измишљеног јунака серије доживљава као стварног, тј. стварнијег од његовог ближњег? И ко је ту стварно жив, а ко привидно? И шта је ту смешно кад је све много тужно, тужно као живот просечног грађанина у Србији средином деведесетих година 20. века?

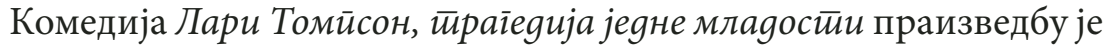
имала у Звездара театру у октобру 1996. године. Историјски, та 1996. године је прва година након Дејтонског споразума - формалног краја рата на просторима Босне и Херцеговине - суноврата онога што се звало југословенска држава и југословенски културни простор у коме је рођен и чији део је био и сам Ковачевић. У време када је комад писан и припремана представа у току су биле и припреме за локалне изборе у Србији на којима је удружена опозиција први пут однела победу над Слободаном Милошевићем. Док се на сцени Звездара театра буде играо Лари Томйсон на улицама Београда трајаће дуги и вишемесечни (углавном мирни) протести присталица опозиције и студената због изборне крађе у другом кругу локалних избора. У то време постала је сасвим јасна велика важност медија, односно начина на који медији интерпретирају догађаје из реалног живота. Упоредо са изборима и протестима водила се медијска битка: различита интерпретација истих догађаја, те истицање једних и прећуткивање и извртање других на медијском пољу Србије добило је пун замах. Напоредо са ширењем (дез)информација о изборима и протестима, велику пажњу ТВ публике привлачиле су иностране мамутске мелодраматичне и акционе серије и ТВ емисије модерних пророка и врачева. Уметност, а нарочито позориште, доживљавани су као својеврсни отпор естетском и интелектуалном сатирању нације. За контекст настанка драме и представе Лари Томйсон веома је важна чињеница да је током рата деведесетих у интелектуалним и позоришним круговима у Београду покренуто питање да ли представе треба да се играју током рата, или уметници треба да зауставе рад у знак протеста. Ово питање је у преформулисаном облику поново постало актуелно током вишемесечних демонстрација у којима су многи уметници узели активно учешће.

Сви ови догађаји су директно и индиректно присутни у комедији Лари Томйсон. Главни јунак, глумац Стефан Нос, одбија да игра у представи Сирано јер и позориште и живот доживљава као бесмислене у тој и таквој земљи. С друге стране, управница Катарина и 
глумац Бели на све начине покушавају да се представа ипак одржи управо зарад духовне и естетске подршке народу, тј. публици у тешкој друштвеној и економској ситуацији. У том подухвату им помажу и одмажу позоришни радници, који су у међусобном рату због плата које нису примили месецима, наоружани специјалац, који јури криминалце и пребија позоришне раднике, и Величанствена Публика, коју „игра“ стварна публика. Други део заплета чине догађаји у породици Нос. Стриц и стрина Нос и кумови породице Нос су грађани који живе у великој беди, а коју не примећују (као што не примећују ни душевну патњу Стефана Носа), захваљујући томе што су опчињени ТВ серијом о патњама младића Ларија Томпсона у неправедној и далекој Аустралији. У гледању серије их омета Електричар који им (као и позоришту) сече струју због неплаћених рачуна. Читав случај добија фаталне размере које успешно разрешава чудесни врач Оливер и његова привидно жива жена Оливера: врач на крају привидно оживљава све погинуле, осим глумца Стефана Носа. У односу према Стефану Носу (који током читавог комада жели да се убије, а на крају једини привидно не оживи), Катарини, Белом и Величанственој Публици види се најјасније нови приступ комедији који је близак пиранделовском „хуморизму“: „Субјекат се осећа као да је подвојен, хоће да се смеје, и смеје се, али га у целој тој акцији нешто спречава, нешто што долази од самог предмета“ (Перишић 2010: 131). Ово је, наравно, веома блиско ономе како смех и сузе у савременом позоришту види Стајан када пише о учинку црне комедије на савременог гледаоца (Styan 1962: 250). Подвојеност долази од тога што стварна публика на представи „глуми“ Величанствену Публику у позоришту које води Катарина и на тај начин постаје саучесник дешавања и репрезент „привидно живог народа“. У интервјуу поводом премијере, Душан Ковачевић је изјавио: „А ми управо трпимо одлагање наших живота и нико озбиљно ништа не предузима, као публика у том комаду“ (Ж. J. 1996: 13). Другим речима, читав комад је комичка метафора за позицију грађана Србије, уметника у Србији и самог аутора кога у комаду најдиректније репрезентује „наратор“ сакривен у дидаскалијама (а који се први пут наслућује у Свейом Георіију). Но то није оно Нушићево „А шта се ви церекате мојој судбини? [...] јер, ко зна, данас-сутра могу ја опет да будем министарка. Само да се заборави ово нешто мало бруке..." са краја Госйође минисйарке (Нушић 1987: 182), већ један горки увид у сопствену ситуацију и сопствену одговорност за позицију у којој се субјекат налази и која је за њега неповољна, готово трагична, а ипак достојна смеха. С друге стране смех, по Бергсону, захтева дистанцу од онога коме (или чему) се смејемо (Бергсон 2004), а како заузети дистанцу према себи, дистанцу према ситуацији коју најболније осећамо, како да уметност испуни мисију коју јој је задао Стерија у Роgољуйцима?믈 Смех је ултимативно

1 „Докле се год будемо само хвалили, слабости и погрешке прикривали, у повјесници учили колико је ко од предака наши['] јуначки глава одрубио, а не и гди је с пута сишао, 
потребан јер је ситуација смешна, али истовремено субјект смеха је и објект смеха. Ову напетост Ковачевић разрешава кроз врсту комике која је блиска наведеној Пиранделовој идеји о хуморизму у коме се субјекат истовремено смеје и саосећа са оним коме се смеје. Овде неко може поставити питање: а зашто аутор није ишао до краја, зашто смех није потпуно превладао и да ли у некој будућој поставци редитељ треба да буде вођен Женетовом тезом да „смех увек побеђује сузе: можемо се смејати ономе због чега смо плакали, нећемо више плакати због онога чему смо се смејали“ (Женет 2002: 161)? Међутим, двадесет једну године од премијере Ларија Томйсона, када се пред публиком појавио најновији комад Душана Ковачевића Хuйноза јеgне љу бави, уочавамо да та подвојеност „хуморизма“ постоји и даље у несмањеном облику, с тим што су у небеса ономад отишли старији припадници породице Нос, а у Хйннози на пут ка звездама крећу млађи. Ова ситуација има веома много везе са бујањем носталгије у нашем друштву и то носталгије како је види Бодријар, а која се јавља када се губи осећај за то шта се стварно догодило у прошлости и због чега се повампирују митови и различити видови „истине“ (Бодријар 1991). Заиста, носталгичност у овом бодријаровском смислу све је више присутна како у делу Душана Ковачевића тако и у саморазумевању нашег друштва. Недостатак нових визија и губитак јасне представе о томе шта се јесте, а шта се није догодило и од чега се састоји историја отвара широм врата носталгији.

Критичари који су били на премијери Ларија Томйсона одмах су уочили да Душан Ковачевић понавља теме и форму претходних комедија, али су имали прилично подељено мишљење о вредностима нове комедије. Док Владимир Стаменковић овај комад доживљава као слаб, а ликове папирнате (Стаменковић 1996: 42-44), Иван Меденица истиче постмодерност комада (Меденица 1996: 24). Оно што одмах можемо да приметимо јесте сличност главног јунака Стефана Носа са неким претходним јунацима Ковачевићевих комада. Он је неуспешни побуњеник против система који репрезентује (не)нормална (српска) породица, као што је то и Мирко Топаловић у комаду

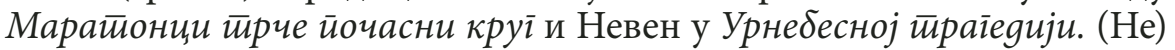
нормална (српска) породица Нос, која је у урбани контекст ставила своје руралне и патријархалне навике, по својим људским карактеристикама и способностима мултиплицирања асоцира на Топаловиће и Вилотиће (Раgован тирећu). Породица Нос је фасцинирана јунаком иностране ТВ серије баш као и Радован (Раgован йрећu). Занимање за парадоксе живота у позоришту Душан Ковачевић је показао у својим комедијама с краја осамдесетих и почетка деведесетих (Клаустирофобична комеgија и Урнебесна йраїеgија). Судар реалног и иреалног присутан је у његовим комадима од самог почетка (Раgован йрећи, Сабирни ценйар, Светии Георіије убива ажgаху). Опсесивни

донде ћемо [']рамати и ни за длаку нећемо бити бољи..." (Поповић Стерија 2014: 379) 
јунаци који, будући да су кућни тирани, намећу своје илузије осталима, такође су стални елемент Ковачевићевих комедија (Радован (Раgован тирећи), Илија Чворовић (Балкански шиичјун), Василије (Урнебесна йраїеgија)). Улогу писца у савременом друштву разматрао је најпре у Клаустирофобичној комедији, а затим и у Професионалиу. Но оно што Ларија Томйсона чини посебно „сличним“ претходним Ковачевићевим комедијама јесте смех до смрти и смех упућен смрти. Ову карактеристику видели смо раније у Марайонцима и Сабирном центиру. У раним комадима, Душан Ковачевић ставља публику у позицију оне која ликове може да посматра са значајне дистанце, тако да и сама смрт може бити предмет смеха, иако је смрт у основној жанровској подели предмет интересовања трагедије. Управо из тог разлога, Ковачевићеве комедије су доживљаване као мрачне и као оне у којима, супротно од класичних комедија, тријумфује Зло над Добрим (Стаменковић 1987). На ову тврдњу можемо додати Суриоов коментар да нема чисто комичке ситуације, да свака комичка ситуација нужно садржи драмску могућност (драмску димензију) и да драмско претходи комичном (Сурио 1982: 39).

Томе најближи од свих Ковачевићевих комада пре Ларија Томйсона свакако је Светии Георіије убива ажgаху. У Свейом Георіију први пут почиње да се појављује индиција да је драма „драматизација ненаписаног романа“. У овом комаду драмска радња се веома често зауставља и губи у меандрима приповедања, а у Професионалиу читав комад ће постати једно велико приповедање Луке Лабана. У Ларију Томйсону, осим класичног приповедања (као на пример када Бели прича о томе како је оседео или како умало нису изгинули због прасета, што је присутно и у претходним комадима), појављује се и невидљиви наратор који најдиректније представља писца, а у комаду је „сакривен“ у дидаскалијама стварајући од комедије драмски роман. Владимир Стаменковић примећује да се инверзија „драмског у комичко постиже тиме што се прича гротескно изобличује, и у детаљима и у целини [...] апсурдно се појављује у уверљивом контексту свакидашњег, вероватно с психолошког становишта" (Стаменковић 1987: 279). Ово се понавља у Марайонцима, Раgовану Трећем, Балканском шииијуну, Сабирном ценіиру, Урнебесној йраїеgији, а породица Нос је настављач ове тенденције. Стаменковић се са тим није сложио, но породица Нос јесте појачана (гротескна у детаљима) слика српске породице из деведесетих која лоше одевена седи код куће и пљује у екран (Ковачевић 2007: 32). Ова реченица из Ларија Томйсона добро истиче парадокс на коме се од почетка заснивала комика Душана Ковачевића и чини га блиским театру апсурда као „трагедија која се изражава кроз комичну метафору“"(Селенић 1971: 37).

Слободан Селенић у есеју посвећеном театру апсурда пише о трагичној фарси, као „комедији која је прерушена трагедија или трагедија која се изражава кроз комичну метафору“ (Селенић 1971: 37). 
Теза о комедији која је прерушена трагедија може се применити на комедије Душана Ковачевића, а може се наслутити и у Стеријиним Роgољуйиима и Нушићевом Покојнику. Најуспешније српске комедије саздане су од комичних ситуација са трагичним последицама. Публика их воли јер у њима наслућује слику сопственог друштва које је изгубило величанствени патос и са њим дотадашњи смисао и правац. Међутим, ако је комедија наш највиталнији жанр да ли нас то, можда, не наводи на помисао да је у сваком добу савременицима њихова ситуација била таква да су је могли адекватно прихватити само кроз комедију, а да је тек ретроактивно, кроз ружичасте наочаре идеологије историјских победника, она будућим генерацијама представљана једнозначно и праволинијски као трагедија или макар велика драма, да би онда те нове генерације, суочене са осећањем неподношљивости (апсурдности?) сопствене ситуације, на своју ситуацију поново реаговали комедијом као и претходна генерација? Да ли је то разлог зашто је комедија (по)стала наш највиталнији (практично једини) драмски жанр који у континуитету опстаје на српским сценама од Стерије до Ковачевића? Потпуно пропадање у Ковачевићевим комедијама огледа се у урушавању реалитета у симулакрум, урушавање истине у лаж, урушавање система у хаос. Комичко је ту начин да се кроз форму драмског раскринка, разјасни, разоткрије ово антиживотно, смртоносно и апсурдно урушавање живота у заједници, која, не могавши да изабере живот, бира смрт. Међутим, мисао о смрти само је још једна апстракција, а писац бирајући да пише бира живот и то нас враћа комедији, односно њеној подврсти сатири, коју и Стајан и Гутке сматрају блиском трагикомедији. Комичко пружа начин да се превазиђе „непремостиво“, а сатира постаје израз надмоћи немоћног. Писац је немоћан да се супротстави појави и људима који праве појаву, али мора да реагује и једини начин на који може да реагује јесте да им се супериорно насмеје кроз сатиру и то је жесток реванш, како то закључује и сам Молијер: „Човек хоће да буде рђав, али нипошто неће да буде смешан“ (Молијер 1976: 483). Тако сатирични смех постаје и израз слободе појединца над присилама друштва и насилницима који би да репрезентују то друштво.

Душан Ковачевић, како је већ речено, користи бројна комичка средства која је употребљавао и у ранијим комадима (опширнију анализу о томе видети у студији Паралеле и сусретиаюа - Душан Ковачевић и Алексанgар Пойовић (Јакшић Провчи 2012)), али он их овде надограђује новом ситуацијом: парадоксом позоришта у позоришту. Комад почиње тако што се реална публика ставља у супериорну позицију у односу на ликове. То је поступак познат као драмска иронија. Иза завесе, глумац Бели и Управница препиру се око тога како да публици објасне да представа касни и како да учине да публика не оде из позоришта иако не могу да играју представу јер 
немају главног глумца. Они говоре као да их ми (публика) не чујемо, а ми њихов дијалог пратимо као радио драму, што код нас изазива осећај комичне напетости. Сцену изненада прекида вика - радници се туку пајсером. Комични интензитет се појачава вишеструко: јунаци се налазе у апсурдној ситуацији - у институцији културе се туку као у друмској механи, а позориште које се води крилатицом show must go on не може да игра представу јер нема главног глумца. Уметници и управница пред публиком желе да сачувају кредибилитет институције културе, иако је све око њих далеко и од респекта, и од културе, и од грађанског. Комична ситуација је појачана комичним дијалогом и игром речима. Обратимо пажњу како реч „пајсер“ појачава комични ритам у дијалогу и како то што Катарина не зна а Бели зна да изговор речи „пајсер“ одређује њихове карактере и међусобни однос:

ГЛАС УПРАВНИЦЕ: [...] Ја нисам глумица, ја не умем да „глумим лудило“! Кад ја полудим, онда ћу стварно бити луда и стварно ћу да направим триста чуда! Оставићу вас: вратићу се мужу у Клагенфурт [...] Ни ја нисам примила плату два месеца, па никога не бијем тим... тим... тим...

ГЛАС БЕЛОГ: Пајсером.

ГЛАС УПРАВНИЦЕ: Никог нисам ударила! Трудим се да преживим ово ужасно време као иоле културни и поштени људи, а ви ми, кад год можете, забадате нож у леђа! Уместо да живим у Клагенфурту као госпођа [...] ја овде сваки дан доживим по три инфаркта! Зашто?! [...] Због вас који се бијете тим... тим... тим...

ГЛАС БЕЛОГ: Пајсером.

ГЛАС УПРАВНИЦЕ: Тим... тим... гвожђем по леђима! [...] Шта ми то овде играмо, какав то морал и етикету „продајемо“ људима, кад у нашој кући људски живот не вреди ни 1000 марака?!

ГЛАС БЕЛОГ: Госпођо, молим вас. Смирите се, молим вас. Стварно ће вас ударити инфаркт. Умрећете, госпођо.

ГЛАС УПРАВНИЦЕ: Нек умрем! Нек умрем кад сам будала! Боље да умрем него сутра људи да показују прстом на мене, да ми говоре иза леђа како сам била неспособна, како је „због мене“ радник убио радника... са... са...

ГЛАС БЕЛОГ: Пајсером... Смирите се, молим вас. (Ковачевић 2007: $15-16)$

Дијалог обилује језичким поигравањима карактеристичним за Ковачевића, као што су бесмислене изјаве („Кад ја полудим, онда ћу стварно бити луда“), погрешна употреба речи у комбинацији са црним хумором који произлази из разумевања менталитета и друштвене ситуације („Шта ми то овде играмо, какав то морал и

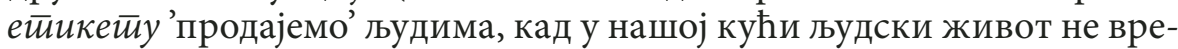
ди ни 1000 марака?!"). 
Душан Ковачевић показује велико разумевање за позоришни миље и радо иронизује патетику и песничке метафоре којима је овај миље склон: „Неће се моја публика враћати кући оборене главе, гледајући у асфалт мрачних улица, док по њима пада киша и увредљиви погледи оних који знају да су кренули у позориште а представу нису видели“ (Ковачевић 2007: 17). Таман кад су Бели и Управница Катарина помислили да контролишу ситуацију, тј. да су убедили публику да је све у реду (мада није), ескалира туча међу радницима, а онда следи још један изненадни заокрет: у позориште упадају лопови, а за њима и наоружани специјалац. Пиранделовско позориште у позоришту на начин Душана Ковачевића хвата замах.

„Ти ћеш мене да бијеш! Мене ћеш да бијеш!“ [...] Уз свако „мене“, као ехо, одјекнуо би туп ударац и јаук неког који је молио: „Нисам хтео! Нисам хтео! Нисам хтео!“... Мрачну страшну „звучну представу“ иза завезе неко је решио да сакрије од публике; са озвучења је прво тихо, а онда све гласније како су се појачавале батине [...] чула песма која је бивала све гласнија и гласнија, док коначно није покрила „немио догађај“. Том Џонс је певао из све снаге: Зелена, зелена йрава gома мої. (Ковачевић 2007: 23-24)

Тврдоглави, комични, апсурдни и трагикомични покушаји глумаца да упркос свему задрже публику у име уметности и позоришта асоцирају на борбу грађана Србије да воде „нормалан“ грађански живот са свим припадајућим вредностима и поред рата, санкција, хиперинфлације. Они су та публика која је дошла у позориште, а због свог останка у њему (ради уметности) постали су неми сведок распада система, хаоса и насиља који се прикривају веселим шлагерима и поезијом.

Радња се из позоришта сели у стан породице Нос у којој старији чланови гледају омиљену серију, а најмлађи, глумац Стефан Нос, уместо да оде у позориште и игра Сирана хоће да се обеси. Радња почиње дијалогом који врло јасно указује на бесмисао и суровост, а који је типичан за Ковачевићеве ликове: „Стефане, немој да се вешаш о лустер! Ако 'оћеш да се бесиш, изађи у двориште па се вешај! Лустер ми не дирај!“ (Ковачевић 2007: 28) И док породица занемарује свог члана, дрхтећи истовремено над судбином измишљеног јунака серије, Ковачевић прави комичке алузије на ситуацију у друштву кроз реченичну конструкцију типичну за урбани говор у коме су остали слојеви руралног: „Ја вам кажем, оти’ће тај запад у пичку материну! Има да пукне ко кеса! Јебо ја тај систем у коме могу младом човеку да наместе проневеру од пет милиона долара“ (Ковачевић 2007: 29). Или: „После пет година колеџа, педесет година робије. Е јебем те земљо која си у стању младе људе да уништаваш, сатиреш и газиш! Која ти је будућност без младости, мајку ли ти јебем!“"(Ковачевић 2007: 30) Псовка игра значајну улогу у комичком стилу Душана Ковачевића. Она је менталитетска одредница, реч која замењује све речи када оне постану недовољне да изразе емоцију и средство комичког одушка. 
У наставку следи двострука игра српског театра апсурда: с једне стране настаје драма јер је породици Нос „исечена серија, тј. струја (пример игре речима), док истовремено Катарина покушава да пресече конопац и спасе глумца Стефана Носа од смрти. Након тога имамо патетичну љубавну сцену између глумца и управнице која као да је изашла из серије коју гледа породица Нос, али са обавезним, ковачевићевским, осећањем за парадокс: „после сваке представе имам прелом душе“, ауторонију: „Нисмо ми плаћени да се убијамо, да одузимамо себи живот, већ да неком живот пружимо“ (Ковачевић 2007: 39) и за претеривање до бесмисла „Кад бих умро данас, у подне, а увече имао представу, дошао бих мртав да играм“ (Ковачевић 2007: 41). Са причом из живота позоришта завршава се први чин и почиње други. Глумац Бели има додатни проблем. Осим што мора да забавља публику, мора да спречи колеге да одустану од позоришта јер Стефана и Катарине нема па нема. Душан Ковачевић сцене гради на принципима игре са парадоксима супротности: док Бели покушава да задржи публику и глумце да не оду јер ће представе сигурно бити, дотле породица Нос у свом стану осуђује и спречава глумца да иде да игра представу - није ред да се „глупира“ кад у кући лежи четворо мртвих рођака. Комично мултипликовање и увећавање до граница апсурда јесу карактеристике и претходних Ковачевићевих комада.

Нови моменат је цитирање и реферисање на друга уметничка дела. Кроз ову комедију аутор ствара постмодерни резиме својих дотадашњих тема и драматуршких поступака, осврт на авангардна стремљења средине у којој је уметнички стасао и tribute значајним српским књижевницима и интелектуалцима (интелектуални круг око Атељеа 212 почетком седамдесетих, коме је припадао и Ковачевић на почетку каријере). Реферисање на друга дела српских аутора уочила је Александра Кузмић у студији Слика свети у gрамама Душана Ковачевића, а ми можемо да додамо да се за потпуно разумевање начина на који Ковачевић користи цитате треба осврнути

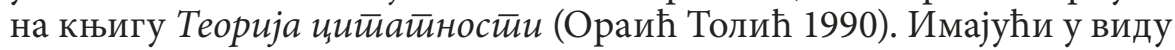
шта ауторка пише о употреби цитата у уметничким делима, нарочито у авангарди, можемо њена запажања пренети и на Душана Ковачевића и његов уметнички и интелектуални круг. У Ларију Томйсону укупна историја савременог српског театра (нарочито онај део који је везан за интелектуални круг око Атељеа 212) јесте једна велика заједница у којој се познати фрагменти различитих писаца стапају и мешају са његовим текстом у једну велику целину. Главне асоцијације на дела других аутора јесу асоцијације на познате реченице глумца Зорана Радмиловића, управницу Атељеа 212 Миру Траиловић, поетско виђење позоришта Данила Киша, као и коментар на Симовићеву идеју о мисији позоришта у тешким временима. Посебно је инспиративно поређење ситуације у којој се нашао глумац Нос нас- 
прам Специјалца. Та сцена је практично коментар на сцену са краја

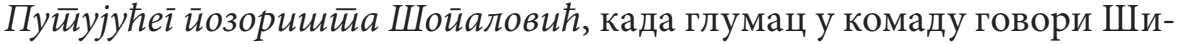
лерове стихове, а непросвећени полицајци пуцају у њега, мислећи да он признаје убиство и да хоће да их нападне. Последица овог чина у Симовићевом комаду јесте та да је млади илегалац ослобођен оптужбе - уметник својом уметношћу спасава борца за слободу. У Ларију Томйсону глумац Нос говори стихове из Сирана. Непросвећени а наоружани Специјалац помисли да глумац хоће да га нападне и пуца у њега. Несрећни глумац гине, не успевајући својом бесмисленом жртвом икога да спасе, нити да било шта промени. Штавише, он остаје заувек мртав, а несрећна управница Катарина и глумац Бели губе и последњи аргумент да задрже публику у позоришту. При почетку друштвених заокрета средином осамдесетих, Симовић још верује да уметност може да спасе душу (а можда и живот) човека. Десет година касније Душан Ковачевић нема ту веру. Сви су мртви - неки привидно, а неки стварно, а „позориште постоји као нека врста анестезије. Није лек, али је сигурно утеха“ (Ковачевић, 2007: 39). И након свега остаје пајсер - пајсер је реч којом се често поиграва Душан Ковачевић у овом комаду. Пајсер означава једноставну алатку. У српској комедиографији Александар Поповић се најчешће поигравао са именима алата и занатлијским изразима. Реч „пајсер“ у овом комаду прелази слободно из света позоришта у свет породице Нос као увек ефикасно (и брутално) средство за решавање сукоба (тј. пребијање људи). Необични, готово комични назив ове алатке делује као метафора живота ових јунака. Иначе, тог октобра, заједно за Ларијем Томйсоном, управо на сцени Звездара театра биће изведена праизведба последње комедије (фарсе) Александра Поповића - Баш бунар.

\section{Закључак који то није, или кад позоришна историја пише драме}

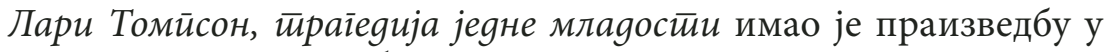
Звездара театру 26. октобра 1996. године у поставци самог писца. Комад је на репертоару остао осамнаест година и изведен је 312 пута. Представа је учествовала на Стеријином позорју 1997. године. Душан Ковачевић није добио Стеријину награду за Ларија Томйсона (награду је добио Горан Марковић за драму Турнеја). Те, 1997. године први пут на Стеријином позорју појавила се једна сасвим млада списатељица - Биљана Србљановић, са праизведбом студентске драме Беоіраgска йрилоіија. То је био њен рад са треће године драматур-

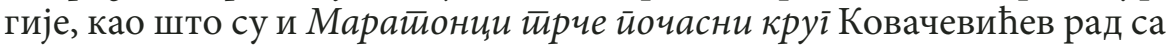
треће године. Оба рада писана су код истог професора - Владимира Стаменковића. Урбана легенда каже да је обе драме управо професор однео у позоришта: Марайонце у Атеље (где ће бити изведена 
друга Биљанина драма Пороgичне йриче, за коју ће добити прву Стеријину награду), а Беоіраgску тирилоїију у ЈДП (праизведба Трилоіије биће на сцени „Бојан Ступица“, на којој је праизведбу имао и Балкански шиијјун Душана Ковачевића, комад за који ће он добити своју прву Стеријину награду). Владимир Стаменковић је као критичар и театролог својим текстовима значајно допринео промоцији и добром разумевању оба писца, а Душана Ковачевића је посебно постулирао као најзначајнијег српског комедиографа након Бранислава Нушића (Стаменковић 1987). Шта се дешава са српском комедијом као жанром након Душана Ковачевића? Ковачевић представља последњу „карику“ у том низу, још је активан - његов комедиографски опус (на срећу!) није заокружен. Поред Душана Ковачевића, савремене комедије пише још неколицина драмских писаца. Најпознатији су сигурно Стеван Копривица (Дуїо йуйоваюу у Јевройу, Мјешовити брак, Ми чекамо бебу...) и Небојша Ромчевић (Лаки комаg, Параgокс, ПР). Док се интересовање Стевана Копривице креће од комедије нарави (Дуіо йуйоваюе у Јевройy), до романтичне комедије

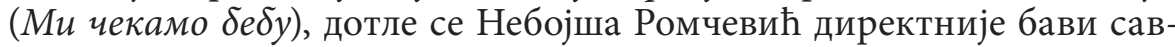
ременим друштвеним феноменима. Ипак, Ромчевић и Копривица су се постепено окренули филму и ТВ серијама, остављајући рад у позоришту у другом плану.

На почетку 21. века појавило се неколико занимљивих комада који могу бити сврстани у комедије, као на пример: He иїрај на Енілезе Владимира Ђурђевића или Илустирована енциклойеgија несйајаньа Божидара Кнежевића. Међутим, реч је углавном о појединачним драмама појединих писаца. Стиче се утисак да се након Душана Ковачевића не наслућује нови српски комедиограф 21. века чија би дела имала позоришни, књижевни и друштвени одзив који имају дела наведених аутора. Зашто 21. век још чека свог комедиографа и да ли ће га уопште дочекати? Од почетка 21. века појавио се читав низ нових драмских писаца и списатељица (Биљана Србљановић, Милена Марковић, Маја Пелевић, Олга Димитријевић, Филип Вујошевић) који су добили јавно признање и подршку, али практично нико од њих не пише комедије. Да ли је Душан Ковачевић последњи велики српски комедиограф? Док чекамо са нестрпљењем добро је да се подсетимо: Између последње Стеријине комедије Роgољуиици и прве комедије Бранислава Нушића Нароgни йосланик прошло је три деценије. ${ }^{2}$ Између последње Нушићеве комедије Покојник (1938) и прве комедије Александра Поповића Љубинко и Десанка (1964) протекло је четврт века. По тој рачуници можемо још да чекамо, само шта и кога, и јесмо ли још увек у стању да се насмејемо сопственој слици у огледалу савремене комедије или ће се комедија, будући да

2 Комедије Косте Трифковића хронолошки долазе између Стерије и Нушића, међутим, он је кратко стварао и углавном је реч о краћим комадима. Такође, он је далеко ређе на репертоару од Стерије и Нушића. 
се у делима Душана Ковачевића све више претвара у црну комедију, на крају сасвим утопити у драму?

Како ће се даље развијати драмски рукопис Душана Ковачевића? Тенденција започета у Ларију Томйсону све више добија на интензитету: преплићу се стварност и илузија, живот и позориште. У Доктиору Шустиеру и Генералној ирроби самоубисиива више никоме није сасвим јасно шта је стварност, а шта илузија, те ко се пред киме лажно представља, ко кога глуми и због чега. У драми Живой у йесним цииеелама читав живот постаје ријалити, да би се у Хийнози јеgне љубави цео космос Ковачевићевих ранијих комедија распрсао у сетној тугованки над изгубљеном младости и потрошеним надама. Позориште се прелило у стварност друштва спектакла. Како се даље смејати и чему? Да ли комедија нестаје из савременог театра или се наново рађа кроз апсурд, црну комедију и трагикомедију? Да ли је наша савремена драма комедија будућности?

\section{ЛИТЕРАТУРА}

Aristotel. O pesničkoj umetnosti. Beograd: Zavod za udžbenike i nastavna sredstva, 1988.

Bentley, Eric. The Life of The Drama. London: Methuen \& Co LTD, 1965.

Bergson, Anri. O smehu. Novi Sad: Vega media, 2004.

Bodrijar, Žan. Simulakrumi i simulacija. Novi Sad: Svetovi, 1991.

Gutke, Karl S. Moderna tragikomedija (istraživanje prirode žanra). Novi Sad: Sterijino pozorje, 2007.

Langer, Suzana. „Velike dramske forme: komični ritam“. Moderna teorija drame. Prir. Mirjana Miočinović. Beograd: Nolit, 1981.

Гоgищњак йозориштиа Србије 2015/16. Нови Сад: Стеријино позорје, 2017.

Ženet, Žerar. „Da umreš od smeha“. Figure V. Novi Sad: Svetovi, 2002.

Јакшић Провчи, Бранка. Паралеле и сусретиана - Душан Ковачевић и Алексанgар Пойовић. Нови Сад: Филозофски факултет, 2012.

Kant, Imanuel. Kritika moći suđenja. Beograd: BIGZ, 1991.

Kovačević, Dušan. Balkanski špijun i druge drame. Beograd: BIGZ, 1983.

Kovačević, Dušan. „Lari Tompson, tragedija jedne mladosti“. Istorija \& iluzija: Antologija najnovije srpske drame. Ur. Vesna Jezerkić, Svetislav Jovanov. Novi Sad: Sterijino pozorje, 2007.

Ковачевић, Душан. Драме I go V. Београд: Завод за уџбенике, 2013.

Кузмић, Александра. Слика светиа у gрамама Душана Ковачевића. Београд: Музеј позоришне уметности Србије, 2014. 
Moliére, Jean-Baptiste Poquelin. „Predgovor Tartifu“. Teorija drame: renesansa i klasicizam. Prir. Jovan Hristić. Beograd: Univerzitet umetnosti u Beogradu, 1976.

Нушић, Ђ. Бранислав. „Госпођа министарка“. Изабране комеguје и gраме II. Прир. Рашко В. Јовановић. Београд: Нолит, 1987.

Oraić Tolić, Dubravka. Teorija citatnosti. Zagreb: Grafički zavod Hrvatske, 1990.

Perišić, Igor. Uvod u teorije smeha. Beograd: Službeni glasnik, 2010.

Pirandello, Luigi. „Humorizam“. Mogućnosti. Split, br. 9, septembar 1963.

Поповић, Јован Стерија. Весела ӣозорја. Нови Сад: Стеријино позорје, 2014.

Selenić, Slobodan. Dramski pravci XX veka. Beograd: Umetnička akademija, 1971.

Stamenković, Vladimir. „Opaska o ljudskoj prirodi“. Pozorište u dramatizovanom društvu. Beograd: Prosveta, 1987.

Surio, Etjen. Dvesta hiljada dramskih situacija. Beograd: Nolit, 1982.

Styan, J. L. The Dark Comedy. Cambridge: Cambridge University Press, 1962.

Frye, Northrop. „Mit proljeća: Komedija”. Anatomija kritike. Zagreb: Naprijed, 1979.

Нова срйска gрама, 2007-2015. Прир. Зоран Ђерић. Нови Сад: Стеријино позорје, 2016.

\section{ЧЛАНЦИ И КРИТИКЕ}

Ј[овановић], Ж[ељко]. „Вечита брига о другима“. Наша борба. 25. 10. 1996, 13.

Меденица, Иван. „Глумац и нос“. Политичка. 29. 10. 1996, 24.

Стаменковић, Владимир. „Глад за савременошћу“. НИН. 1. 11. 1996, 4244.

\section{САЈТОВИ}

https://www.pozorje.org.rs/

https://zvezdarateatar.rs/ 


\author{
Comedy as an Aesthetic Response to Social Challenges: \\ Larry Thompson: A Tragedy of a Youth by Dušan Kovačević - \\ an Example of the Serbian Postmodern Black Comedy
}

Summary

By examining the current theater repertoires in Serbia, the author has reached the conclusion that comedy is the most vital genre in the whole corpus of play-writing in Serbian. The comedies of Sterija, Nušić, Aleksandar Popović and Dušan Kovačević are continually included in the Serbian theaters' repertoires. The paper asks the questions why comedy is our most vital genre, what are the characteristics of the plays written by the last of the abovementioned Serbian comedy playwrights, and what is the connection between satire, black comedy and absurd in the Serbian contemporary comedy represented by Dušan Kovačević.

The paper is testing the offered tenets through a prism of numerous and diverse theoretical studies on comedy, starting from Aristotle to the latest research. We analyze Dušan Kovačević's approach to comedy writing on the example of the drama Larry Thompson: A Tragedy of a Youth, which was written at the midpoint of this playwright's career and combines the features of his early work, the comedies such as The Marathon Family and Radovan, the Third, and his late phase, the dramas like A Dress Rehearsal for a Suicide. Dušan Kovačevićs work is examined in the historical context of the 1990s' political events in Serbia, in the theatrical and artistic context in which the work was created and performed as a theater play, in the context of the Serbian comedy writing from Sterija to Kovačević, with a brief note on the authors appearing in the $21^{\text {st }}$ century. Apart from this, the work of this Serbian playwright is viewed in the context of theoretical studies in the spirit of postmodernism, relevant at the time of the play's creation, and very much visible, although insufficiently noted by contemporaries, and it is viewed through a prism of the most notable and latest research of humor, comedy, and laughter.

The paper reveals that this Kovačević's work is closest to Pirandello in its spirit - closest to Pirandello's idea of the theater within the theater, the testing of the borders between the reality and illusion, and the idea of the comic, which the Italian playwright defines using the term "humorism". A characteristic of the "humorism" is the compassion felt for the person we are laughing at, and starting from Larry Thompson, this increasingly becomes the feature of Dušan Kovačević's dramaturgy in his late phase, although he has not abandoned the black humor characterizing his work from the very beginning, i.e. from The Marathon Family.

At the end of the paper, the author observes that Dušan Kovačević does not have a successor and is still the main representative of the Serbian comedy writing. Considering the whole development of the Serbian comedy from Sterija to Kovačević, the author wonders in which direction and in what manner the comedy will further develop and if it will continue to exist, whether we are still capable of laughing to our own big and small flaws, or whether we will give up on comedy, and what will then be the pivot of the theater repertoires. ernism

Keywords: comedy, black humor, Dušan Kovačević, absurd, theater, postmod- 